\title{
Teaching English to Sanitary Students
}

DOI: https://doi.org/10.47175/rielsj.v2i3.298

\author{
| Akram Hashemi | \\ Faculty of Persian Literature \\ and Foreign Languages \\ Department of English \\ Language Teaching, Islamic \\ Azad University, Roudehen \\ Branch, Iran
}

a.hashemi@ riau.ac.ir

\begin{abstract}
English Specific Course books should fulfill the real needs and objectives of the learners of special fields, actually in Corona arena. This study enjoyed a mixed method that evaluated the public textbook for the professional health, taught at Medical Branch. Two standard questionnaires administered in this research after piloting based on a Likert-scale evaluation checklist and Davoodi's needs analysis questionnaire followed by an interview from the students. Data was analyzed via SPSS software version 22.0 and the findings revealed that the text book entitled "English for professional health students" was suitable for the related course from the students' attitude, but it did not meet the students' actual needs. Moreover, it provided valuable implications for students, teachers, syllabus developers and administrators.

KEYWORDS

attitude; sanitary; health; textbook; needs
\end{abstract}

\section{INTRODUCTION}

They stated course book evaluation has played a significant role in understanding language learning (p.5). In this regard, EAP and ESP have been increasingly required to fulfill the applicants' specific academic needs. English for Specific Purpose is an approach in language teaching in which content and method are based on the learners' aims to learn a language (Hutchinson and Waters, 1987). Moreover, instructional materials and textbooks have been known as a tool for shaping attitudes (Noreen, 2010).

Today, our society is information-based. As the society is changing, our attitues should be dynamic and be accountable to the wider world (Mattheos and Stefanovic, 2008). Hence, education systems are undergoing enormous changes, which includes the most updated knowledge and sets a base for the integrative incorporation of the future knowledge.In addition to, particularly in the higher education area, it was characteristically stated that 'integrating teaching, learning and technology is a mandate, not an option, and doing any less would border on professional irresponsibility'. (Kavadella, 2012).

Hence, he added the main focus of this study was to evaluate comprehensively the students' attitudes regarding the ESP textbooks which are taught for the Midwifery in IAU, medical Branch. Most ESP is not only "a mixture of direct teaching, managing pair and group work,but also assisting students to learn by means of a variety of resources".

So, this study reveals the students' attitude of Islamic Azad university, medical Branch in 2020 ?

\section{RESEARCH METHODS}

The method of study was mixed method and the sampling design was used in this study. The researcher used "English for the professional health, 7rd edition, 2016" textbook. It was the latest published textbook For this purpose. 
Then Davoodi's (2012) students' needs analysis questionnaire was administered at the same time. The last main instrument in this study was an interview that consists of up to 7 questions.

\section{Reliability of the Instruments}

The reliability of instruments were observed carefully (Students' Analysis questionnaire: 0.81 and Students' textbook evaluation: 0.79). Then, the construct validity of the questionnaires was calculated based on factor analysis .

\section{Validation of the Instrument}

First, expert judgment strategy was utilized for content analysis of the interview questionnaire. Three qualified experts were asked to analyze and review the questionnaires in terms of their content, wording, and ambiguity. The expert judgment resulted no modification and revision of some items of the questionnaires, but the experts modified the interview questions to some extent. Second, for the construct validation of Students' Textbook Evaluation Questionnaire and the Students' Need Analysis Questionnaire confirmatory factor analysis (CFA) was used (Brown, 2014). Accordingly, the finalized questionnaires and the validated interview were administered among the participants of the study.

\section{Factor Analysis for Students' Textbook Evaluation Questionnaire}

Using a loading $\geq 0.30$ as the criteria for inclusion of items, the items were clustered around five categories including appropriation language skills, vocabulary, skills and sub-skills, and exercises/activities.

\section{KMO Sampling Adequacy}

The KMO measure for adequacy is higher than 0.6. As can be seen in the below table 1 . The KMO measure indicated 0.72 .

Table 1. Students' Textbook Evaluation Questionnaire

\begin{tabular}{lll}
\hline Kaiser-Meyer-Olkin Measure of Sampling Adequacy & .72 \\
\hline Bartlett's Test of Sphericity & Approx. Chi- & 1015.53 \\
& Square & \\
\hline & Df & 346 \\
& Sig. & .000 \\
\hline
\end{tabular}

Result showed requirement of sampling adequacy was met. The KMO measure indicated 0.72 , as it is shown in above table.

\section{RESULTS AND DISCUSSION}

The results of question : How does the prophesional health textbook reflect the students' attitude of IAU,medical Branch revealed the following information:

(1)Language Skills $(\mathrm{M}=3.77, \mathrm{SD}=2.43)$, (2)Vocabulary $(\mathrm{M}=3.49, \mathrm{SD}=2.45),(3)$ Skills and sub-skills $(\mathrm{M}=3.05, \quad \mathrm{SD}=2.42),(4) \quad$ Appropriation $\quad(\mathrm{M}=2.99, \quad \mathrm{SD}=2.40), \quad$ and(5) Exercises/activities $(\mathrm{M}=2.87, \mathrm{SD}=2.39)$. The results indicated the language skill, vocabulary, and skills and sub-skills of the ESP textbook were highly scored by the students. The findings of the first question was in line (3)with Basturkmen (2006), Brown (1995), Hyland (2006), Mazdayasna and Tahririan (2008), Cai (2013), Eslami (2010), and Movassagh and Soodmand Afshar (2019) who found that needs are constructed by the teacher, the learner, and syllabus designers. 


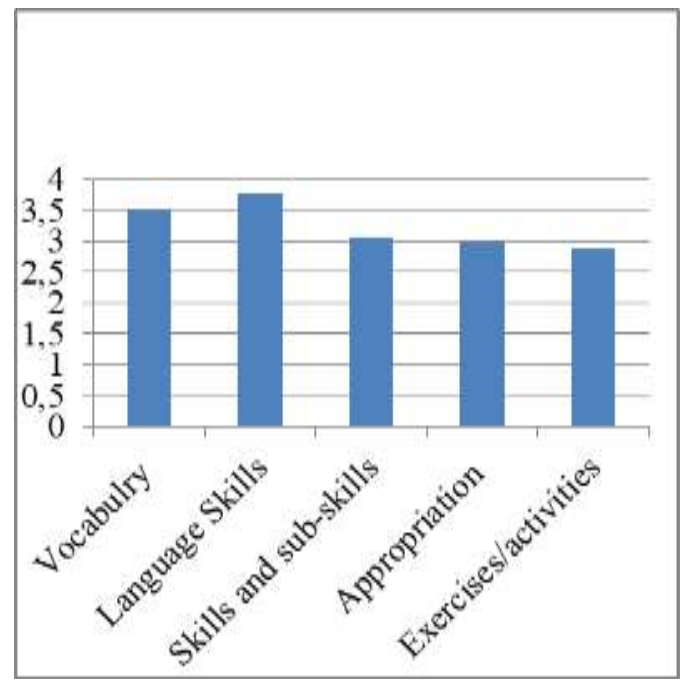

The results in the above figure showed that, the textbook was fairly met sufficient regarding appropriation, activities and skills and sub-skills from the students profesional health' attitudes. On the hand, language skills and vocabulary skills were given the most attention in the ESP textbook. Therefore, it is suitable from students' attitudes in some areas.

Overall analysis of the findings from the students' need analysis questionnaire and the interview indicated that the targeted textbook did not meet the actual language needs of the students in the new millennium of tecnology . In fact, the course did not equip the students with all the technology skills as needed due to weaknesses of the course under study. The most notable point is that there was a gap between the skills taught in the course with regard to the skills required in the advanced technology area during Corona-virus area.

In this regard, "ESP makes use of the underlying methodology and activities of the disciplines it serves" (11). This principle should reflect the processes in the working environment. The above-mentioned approach, however, is contrary to university course requirements, where courses should have a gradable outcome.

\section{CONCLUSION}

Their current extbook did not provide students with genuine, real-life tasks and exercises. In this needs analysis study, the students stated in their interview that their textbook was repleted with grammatical and linguistic structures, general vocabulary, and inappropriate activities. They believed that this textbook is not adequate and fail to satisfy their present and future needs. Therefore, the inclusion of authentic texts and appropriate exercises can help develop language proficiency.

Thus, it can be said that the textbook failed to scaffold students and provide them with necessary skills and strategies to develop language competence. The findings also showed that the textbook is a significant course for dental students especially at higher levels of education. The participants argued that an ESP course would be more successful if it develops their lexical knowledge, particularly specialist vocabulary, speaking and listening skills.

\section{REFERENCES}

Basturkmen, H. (2006). Ideas and Options In English For Specific Purposes. Mahwah, N.J.: Lawrence Erlbaum Associates, Publishers, 2006.

Bradley, M.A., \&Harrell, M.C. (2019). Data collection method, Semi-structured interviews and focus groups. RAND National Defense Research Institute. 
Brindley, (1989). Educating the reflective practitioner: toward a new design for teaching and learning in the professions. San Francisco: Jossey Bass. Retrieved from http://www.rand.org/pubs/technical_reports/TR718.html

Brown, T. A. (2014). Confirmatory Factor Analysis for Applied Research, Second Edition. Guilford Publications, 2015, USA. ISBN: 146251779X,9781462517794.

Davoodi, M (2012). Validating a self-assessment questionnaire on Vocabulary knowledge. TELL, 2(6), 125-154.

Dudley-Evans, T., \& St. John, M. J. (1998). Developments in English for Specific Purposes: A multi-disciplinary approach. Cambridge: Cambridge University Press.

Hutchinson, T., \& Waters, A. (1987). English for specific purposes: A learner-centered approach. Cambridge: Cambridge University Press.

James, M. (2016). The development of ESP in different academic majors. London.

Karahan, F. (2007). Language attitudes of Turkish students towards the English language and its use in Turkish context. Journal of Arts and Sciences Say, 7, 73-87.

Karimi, L., Sadeghi, B., Behnam Nia, F., Esmaeeli Salumahaleh, A., Mirzaei, Kh., \& Farokhzadi, A. (2013). Agricultural extension and rural development ESP textbook evaluation in Bu Ali Sina University, Iran. English Linguistics Research Journal, 2(1), 113-127. Doi: 10.5430/elr.v2n1p.113

Khaki, N., Janati, Y., Shah Hossaini, Z. (2016). English for midvifery students, Samt publishing, Tehran, Iran.

Kavadella, A., Tsiklakis, K., Vougiouklakis, G., \& Lionarakis, A. (2012). Evaluation of a blended learning course for teaching oral radiology to undergraduate dental students. European Journal of Dental Education, 16(1), e88-e95.

Matteos, P \& Stefanovic, O. (2008). English for academic purposes in Neoliberal Universities: A critical grounded theory. London and New York: Springer.

Mazdayasna, G., \& Tahririan, M., H., (2008). Developing a profile of the ESP needs of Iranian students: The case of students of Nursing and Midwifery. Journal of English for Academic Purposes, 7(4): 277-289. Doi: 10/.1016/j.jeap.2998.10.008. Retrieved fromhttps://www.researchgate.net/publication/223233536_Developing_a_profile_of_th e_ESP_needs_of_Iranian_students_The_case_of_students_of_nursing_and_midwifery

Mostafaei Alaei, M., \& Ershadi, A. R. (2017). ESP Program in Iran: A Stakeholder-based Evaluation of the Program's Goal, Methodology, and Textbook. Issues in Language Teaching, 5(2), 306-279.

Movassagh, Soodmand Afshar, (2016). Investigating the English language needs of thepetroleum engineering students at Hardhamount University of Science and Technology. The Asian ESP Journal, 4(1), 6-34.

Munby, J. (1978). Communicative syllabus design. Cambridge: Cambridge University Press.

Nooreen N., \& Arshad, A.A. (2010). Examining the importance of EST and ESL textbooks and materials: objectives, content and form. Retrieved from http://www.espworld.info/Articles_9/textbooks.htm

Tripathi, P. (2017). Critical English for Academic Purposes: Theory, Politics, and Practice. Mahwah/New Jersey: Lawrence Erlbaum Associates, Publishers.

Zainol-Abidini, M. J., Pour-Mohammadi, M., \& Alzwari, H. (2012). EFL Students' Attitudes towards Learning English Language: The Case of Libyan Secondary School Student. Asian Social Science, 8(2), 119-134.

Zhang, X. (2017). A critical review of literature on English language teaching textbook evaluation: What systemic functional linguistics can offer? Journal of Language and Cultural Education, 5(1), 78-102. 